\title{
Krok ku ucieleśnieniu poznania. Uwagi wstępne do pracy Andrew D. Wilsona i Sabriny Golonki
}

\author{
Przemysław Nowakowski \\ Zakład Epistemologii i Kognitywistyki \\ Uniwersytet Mikołaja Kopernika w Toruniu \\ pnowakowski[]avant.edu.pl \\ Otrzymano i zaakceptowano: czerwiec 2014; opublikowano: lato 2014.
}

\begin{abstract}
Abstrakt
Tekst ten stanowi krótkie wprowadzenie do artykułu Andrew D. Wilsona i Sabriny Golonki „Ucieleśnienie poznania to nie to, co myślisz” (w tym numerze). Rozważamy w nim proponowaną przez tych autorów koncepcję ucieleśnienia, wskazując na obecne w niej napięcia teoretyczne, jej zalety i słabości.
\end{abstract}

Słowa kluczowe: poznanie ucieleśnione; strategia zastępowania; zasoby poznawcze; zadanie poznawcze; symulacja.

\section{Wprowadzenie}

Praca Andrew D. Wilsona i Sabriny Golonki „Ucieleśnienie poznania to nie to, co myślisz", której przekład prezentujemy poniżej, oferuje niezwykle interesującą próbę metodologicznego ujęcia poznania ucieleśnionego. W tekście, jak i na swoim blogu ${ }^{2}$ autorzy ci argumentują za tym, że nie każdy związek między ciałem a poznaniem zasługuje na wyżej wspomniane miano. Kiedy staramy się wykazać, że taki a taki proces poznawczy jest ucieleśniony, powinniśmy w pierwszej kolejności zidentyfikować związane z tym procesem zadanie poznawcze $Z_{p}$. Następnie, wyjaśniając realizację tego zadania, powinniśmy:

(a) wskazać zasoby niezbędne do zrealizowania zadania poznawczego $Z_{p}$,

(b) wykazać, że w realizacji zadania poznawczego $Z_{p}$ ciało lub jakieś jego funkcje stanowią przynajmniej część tych zasobów.

Na podstawie (a) i (b) można wykazać, czy i jaką rolę pełni, lub też jak ciało uczestniczy w realizacji zadania poznawczego $\mathrm{Z}_{\mathrm{p}}$.

\footnotetext{
${ }^{2}$ http://psychsciencenotes.blogspot.com
} 
W swoich dociekaniach Wilson i Golonka (w tym numerze) sięgają po dystynkcję zaproponowaną przez Shapiro (2011). Autor ten w pierwszej pełnej i jak sądzimy - satysfakcjonującej monografii poświęconej poznaniu ucieleśnionemu wyróżnia trzy możliwe postawy w badaniach nad poznaniem ucieleśnionym: konceptualizację, konstytucję i zastąienie.

(i) konceptualizacja - ciało ogranicza i determinuje to, jakie pojęcia możemy nabywać, oraz to, jak konceptualizujemy świat i samych siebie,

(ii) konstytucja - ciało (również poza mózgiem) i środowisko konstytuują procesy poznawcze,

(iii) zastąpienie - ciało, jego stany i procesy, włączone w interakcję $\mathrm{z}$ otoczeniem (dynamika tej interakcji), zastępują w wyjaśnianiu poznania dotychczasowe pojęcia reprezentacji i obliczeń.

Wilson i Golonka (w tym numerze) uznają, że tylko (iii) prowadzi do autentycznego, a nie pozorowanego ucieleśnienia poznania. Autentyczne ucieleśnienie ${ }^{3}$ musi wiązać się z zerwaniem ciągłości (to samo głoszą zwolennicy tak zwanego radykalnego ucieleśnienia poznania) między kognitywistyką klasyczną a ucieleśnioną i propozycją zupełnie nowych konceptualizacji starych - kognitywistycznych - problemów. Rozwiązania (i) i (ii) jako akcentujące ciągłość między ujęciami klasycznymi a ucieleśnionymi należy odrzucić. Stąd prezentowana w (a) i (b) strategia jest strategią zastępowania dotychczasowych wyjaśnień procesów poznawczych wyjaśnieniami opartymi na dynamice ciała zanurzonego w środowisku (naturalnym i społecznym) i zaangażowanego w realizację zadań w świecie. O tym, w jakim stopniu pokazana tutaj strategia jest skuteczna, mogą się Państwo przekonać, czytając prezentowany przez nas przekład pracy Wilsona i Golonki. Tutaj postaramy się wskazać kilka wątpliwości, które naszym zdaniem wymagają dalszego zbadania.

\section{Kilka wątpliwości}

Po pierwsze wątpliwości dotyczą zasięgu strategii zastępowania w badaniach kognitywistycznych. Po drugie - napięcia pomiędzy ujęciami predykcyjnymi (tu: symulacyjnymi) a ucieleśnionymi. Po trzecie - czy to, co Wilson i Golonka obejmują kategorią ucieleśnienia, faktycznie zasługuje na miano poznania.

\footnotetext{
${ }^{3}$ Ważna uwaga: pojęcia ucieleśnienia używamy tutaj na określenie zarówno samego dyskutowanego charakteru poznania, jak i - zgodnie ze zwyczajem autorów anglojęzycznych - pewnej szeroko rozumianej perspektywy naukowej [red.].
} 
O tym, jak wiele należy zmienić, by ucieleśnić poznanie

Strategia zastępowania, pomimo oczywistych korzyści - dokonując zastępowania, już wiemy, że nasze ujęcie jest ucieleśnione - niesie za sobą pewne zagrożenia. Wspomnimy tu o jednej z nasuwających się wątpliwości: jak wiele należy zastąpić, by ucieleśnić poznanie. Po pierwsze można sądzić, że poznanie jest ucieleśniane wtedy i tylko wtedy, gdy mamy do czynienia $\mathrm{z}$ pełnym zastąpieniem. Pełnym zastąpieniem nazywamy takie, które wyjaśniając realizację $Z_{p}$, odwołuje się wyłącznie do pewnych procesów, funkcji czy własności ciała. Wyjaśnienie, które choćby częściowo odwołuje się do własności umysłowych, obliczeniowych czy innych własności prima facie niecielesnych, nie może być ujęciem ucieleśnionym ${ }^{4}$. Takie ujęcie powoduje, że pełne zastąpienie okazuje się kryterium ucieleśnienia. W tym świetle niepełnego zastąpienia (a więc de facto niezastąpienia) nie można interpretować jako ucieleśnienia.

Po drugie w ramach zastąpienia można zaproponować bardziej liberalne rozstrzygnięcia. Mianowicie takie, które w ramach identyfikowania wskazują na zasoby potrzebne do zrealizowania $Z_{p}$, a więc zarówno ciało, jak i reprezentacje mentalne. To rozwiązanie - jak sądzimy, bardziej płodne naukowo - jest odrzucane przez Wilsona i Golonkę.

Problem, który - jak się wydaje - stoi za tym podziałem, jest następujący. Strategia identyfikowania zasobów jest wyjątkowo liberalna i zgodna z liberalnym podejściem do zastępowania. To powoduje, że choć autorzy wprowadzają strategię identyfikowania zasobów, najwyraźniej dążą do szczególnego - ucieleśnionego - przeszukiwania tych zasobów. To ucieleśnione przeszukiwanie zasobów zdaje się czynić proponowane ujęcie niebezpiecznie dogmatycznym. Podsumowując, oznacza to, że dość liberalna i otwarta strategia identyfikacji zadania i zasobów jest co najmniej niezgodna z zaproponowanym przez Wilsona i Golonkę ujęciem strategii zastępowania, która jest bardzo radykalna, wymagająca i ograniczająca.

Powyższą wątpliwość zobrazujemy jednym z przykładów przedstawionym przez Wilsona i Golonkę: problemem zapolowego.

\footnotetext{
${ }^{4}$ Tu może pojawiać się podejrzenie o błędną interpretację strategii zastępowania. Przecież Shapiro (2011) chodziło o to, że koncepcja ucieleśnienia powinna przedstawić alternatywną względem klasycznej kognitywistyki próbę wyjaśnienia procesów poznawczych, koncepcję, która odwołuje się do ciała i może - jako lepsza - zastąpić dotychczasowe wyjaśnienia. Sądzimy jednak, że Wilson i Golonka (w tym numerze) dążą nie tylko do zastąpienia starych wyjaśnień wyjaśnieniami odwołującymi się do ciała, ale i do zredukowania - w ramach tych wyjaśnień - na ile to możliwe, procesów poznawczych do cielesnych oraz związanych z cielesnym działaniem w świecie i oddziaływaniem na ten świat.
} 


\section{Czy zapolowy nie potrzebuje predykcji?}

Przedstawiając wyjaśnienie problemu zapolowego ${ }^{5}$, Wilson i Golonka kontrastują ze sobą dwa ujęcia. Krytykują koncepcję „internalistyczną”, w której to system poznawczy uznaje się za rodzaj symulatora opierającego swoje działanie na znajomości praw rządzących balistyką piłki futbolowej. W tym ujęciu zapolowy, widząc uderzenie piłki i znając rządzące jej lotem prawa, powinien dzięki symulacji rozstrzygnąć, gdzie wyląduje piłka, i udać się bezpośrednio w to miejsce. W drugim, „eksternalistycznym” i bronionym w artykule ujęciu zapolowy albo koordynuje swój ruch z prędkością lotu, albo z kątem lotu piłki. Kiedy już tempo lotu zostaje uzgodnione $\mathrm{z}$ tempem przemieszczania się, tak że piłka nie zmienia pozycji względem zapolowego, lub też gdy lot piłki nie odchyla się względem zapolowego, to o ile inne warunki nie przeszkodzą, zapolowy powinien złapać piłkę, znajdując się pod koniec jej lotu tam, gdzie ona wyląduje.

Pierwsza strategia odnosi się jedynie do wewnętrznych procesów powiązanych z problemem „gdzie wyląduje piłka”, a druga - preferowana przez Wilsona i Golonkę - jedynie do zewnętrznego procesu relacji między dwoma obiektami: ciałem a piłką. Argumenty tych autorów znajdą Państwo w artykule poniżej, tu przedstawmy kilka wątpliwości dotyczących krytyki ujęć internalistycznych.

Przede wszystkim ze względu na odległość między zapolowym a pałkarzem ten pierwszy nie może mieć - na początku lotu piłki - precyzyjnych danych o położeniu i prędkości lotu obiektu. Stąd system symulujący (predykcyjny) musi uwzględnić tę trudność. Powinien dysponować jakimś sposobem radzenia sobie $\mathrm{z}$ brakiem precyzyjnych informacji. Jeżeli sobie $\mathrm{z}$ tym nie radzi, to nie znaczy, że każde ujęcie symulacyjne (predykcyjne) jest złe, a jedynie, że jest złe to konkretne ujęcie. Nic ponadto.

Clark (2014), analizując to samo zagadnienie, wskazuje na to, że system nieustannie dokonuje predykcji, dostosowując je do zmian, jakie mają miejsce $\mathrm{w}$ jego otoczeniu. To znaczy, że jeżeli wyjaśniamy problem zapolowego symulacyjnie, to musimy pamiętać, że symulacja trwa cały czas, a zmiany warunków powodują zmiany w symulacji i w zachowaniu systemu. Dlatego jeśli nawet system symuluje, to nie znaczy, że od razu poznaje dokładne rozwiązanie problemu, do którego dochodzi w trakcie symulacji. Zmiany sytuacji powodują zmiany w symulacjach, a to generuje zmiany w zachowaniu. Rozsądne wydaje się więc założenie, że zapolowy nieustannie dokonuje predykcji (symulacji), a nie takie, że dokonuje jej raz i następnie przestaje symulować lot piłki.

\footnotetext{
${ }^{5} \mathrm{~W}$ baseballu: zawodnik, który stara się złapać piłkę po wybiciu jej przez pałkarza. Problem zapolowego dotyczy tego, jak pomimo wielu ograniczeń zapolowemu udaje się tę piłkę złapać.
} 
Sądzimy, że ujęcie symulacyjne (predykcyjne) można rozwinąć i to w sposób interesujący. Być może zapolowy, przemieszczając się w kierunku piłki, gromadzi informacje, które pozwalają mu parametryzować rozwiązywany problem. Innymi słowy działanie cielesne nie zastępuje ujęć symulacyjnych (predykcyjnych), ale jest ich częścią. Dzięki działaniu problem się upraszcza, ma miejsce wykorzystanie dodatkowych parametrów (dookreślenie prędkości czy kąta lotu piłki), co czyni rozwiązanie tego problemu łatwiejszym. Ponadto pozwala to na pełniejsze wykorzystanie możliwości systemu symulacyjnego (predykcyjnego), jak angażowanie ruchów balistycznych, czyli na przykład bardzo szybkich ruchów sięgających - tak ważnych dla sięgającego.

Dodatkowo Clark (2014), opierając się na zasadzie rozstrzygania (Daw i inni 2005) - czyli zasadzie, która pozwala rozstrzygać, jaką strategię należy zastosować do rozwiązania konkretnego problemu - sądzi, że czasami pomimo tego, że system działa predykcyjnie, symulując (Clark 2013), najlepszym rozwiązaniem jest zaniechanie predykcji i rozwiązanie problemu dzięki wykorzystaniu bardziej podstawowych informacji, takich jak zgodność prędkości czy kierunku między zapolowym a piłką.

W świetle powyższych przykładów właściwe działanie zapolowego może wymagać zarówno udziału ciała, jak i pewnych form reprezentacji. A to powoduje, że nie wszystkie aspekty rozwiązania proponowanego przez Wilsona i Golonkę wydają się równie satysfakcjonujące i niebudzące wątpliwości.

\section{Drobna uwaga na temat poznania}

Na koniec naszych wątpliwości wspomnijmy o jeszcze jednej. Praca „Ucieleśnienie poznania to nie to, co myślisz” dotyczy poznania ucieleśnionego. Jednak tak jak w przypadku wielu innych prac dotyczących ucieleśnienia, tak i tutaj nie jesteśmy pewni, czy zaprezentowane badania można uznać za par excellence badania nad poznaniem, czy też za badania nad procesami poznawczymi. Co wspólnego z poznaniem ma zachowanie owadów i robotów, problem $A B$, czy też problem zapolowego? $\mathrm{W}$ jakim stopniu te zagadnienia pozwalają nam zrozumieć, czym jest uwaga, pamięć lub wyobraźnia? Nawet gdy Wilson i Golonka podejmują problem języka, to - jak można się przekonać w trakcie lektury artykułu - ich rozwiązanie nie wydaje się eksplorować tych najbardziej poznawczo istotnych aspektów języka i komunikacji językowej.

Wszystko to prowokuje pytania, czy aby autorzy ci nie redukują poznana do zachowania? A jeżeli tak, to czy taka redukcja jest uprawniona? Jak się wydaje, są to pytania, z którymi aktualnie musi mierzyć się wiele koncepcji poznania ucieleśnionego. Tutaj jedynie sygnalizujemy problemy. 


\title{
Zakończenie
}

Mimo powyższych zastrzeżeń i wątpliwości czy nawet wraz z nimi prezentowana poniżej praca stanowi bardzo dobre wprowadzenie do badań nad ucieleśnieniem poznania (dodajmy: silnie osadzone w psychologii ekologicznej). Wprowadzenie, które nikogo nie pozostawi obojętnym. Zwolenników zadowoli, przeciwników sprowokuje do krytyki. Ponadto sądzimy za Shapiro (2014), że każdy najmniejszy nawet krok posuwający do przodu nasze badania nad poznaniem ucieleśnionym jest niezwykle cenny, a praca „Ucieleśnienie poznania to nie to, co myślisz" dokonuje tego kroku.

\section{Literatura}

Clark, A. 2013. Whatever next? Predictive brains, situated agents, and the future of cognitive science. Behavioral and Brain Sciences, 36(03): 181-204.

Clark, A. 2014. Expecting World. Prezentacja z wystąpienia na konferencji Perspectives on Human Probabilistic Inference. Lorenz Center. Leiden, Holandia, 12-16 maja 2014, źródło: http://www.lorentzcenter.nl/lc/web/2014/627/presentations/Andy\%20Clark\%20\%20Expecting\%20the\%20World.pdf, 27.06.2014.

Daw, N. D., Niv, Y., \& Dayan, P. 2005. Uncertainty-based competition between prefrontal and dorsolateral striatal systems for behavioral control. Nature neuroscience, 8(12): 1704-1711.

Shapiro, L. A. 2014. When is cognition embodied? Kriegel, U., red. Current Controversies in Philosophy of Mind, Routledge: 73-90.

Shapiro, L. A. 2011. Embodied cognition. London: Routledge.

\begin{abstract}
The paper is an introduction to the article „Embodied cognition is not what you think it is" by Andrew D. Wilson i Sabrina Golonka. The author comments on their account of embodied cognition based on replacement hypothesis.
\end{abstract}

Keywords: embodied cognition; replacement style; cognitive resources; cognitive task; simulation. 